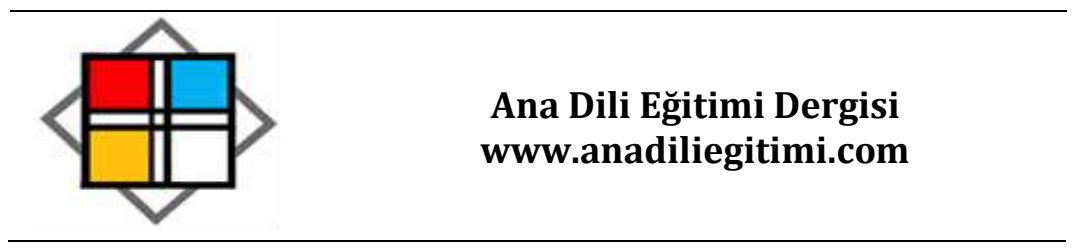

\title{
Türkçe Öğretmenliği Bölümünde Yazma Eğitimi Dersi: Bilme ve Uygulama Karşılaştırması
}

\author{
Filiz METE*
}

Gönderilme: 24.09.2014 / Düzeltme: 05.01.2015 / Kabul Edilme: 08.04.2015

\section{Öz}

Dil eğitiminde amaç, öğrencide dil becerilerini geliştirerek iletişim yeteneklerinin artırılmasıdır. Dil becerileri anlama ve anlatmayı ifade etmektedir. Okuma ve dinleme becerileri anlamanın, konuşma ve yazma becerileri ise anlatmanın kapsamında yer almaktadır. Birey iletişim kurarken kendini sözlü veya yazılı olarak ifade eder. Yazma becerisi okul sürecinde gelişen karmaşık bir eylemdir. Bu çalışmada, Türkçe öğretmen adaylarının metin oluştururken yaptıkları anlatım bozuklukları incelenmiştir. Tespit edilen yanlışlıklar gruplandırılarak eşdeğer düzeyde yanlışların bulunduğu yeni bir metin araştırmacı tarafından oluşturulmuş ve adaylardan metinde bulunan yanlışları tespit edip düzeltmeleri istenmiştir. Daha sonra adayların kendi yaptıkları yanlışlar ile tespit edip düzelttikleri yanlışlar karşılaştırı ışstır. Öğretmen adaylarının kendi yaptıkları yanlışları başkaları yaptığında rahatça tespit edip düzelttiği belirlenmiştir. Bu sonuca göre öğretmen adaylarının anlatım bozukluğuna yol açan yanlışları bildiği ancak kendileri metin oluştururken benzer yanlışları yaptığı söylenebilir. Ortaya çıkan bu durumun nedenleri ise öğretmen adaylarıyla görüşmeler yapılarak araştırılmıştır.

Anahtar kelimeler: Türkçe öğretimi, yazma eğitimi, anlatım bozukluğu.

\section{Writing Course in Turkish Education Department: Comparison to Knowledge and Practice}

\section{Abstract}

The main goal of language education is to improve communication ability of students by developing language skills. Language skills refer to and explaining. Understanding includes reading and listening skills, explaining includes speaking and writing skills. Individuals express themselves orally or in writing while communicating. Writing is a complex action which developed in the process of school. In this study, Turkish teacher candidates' disorders were examined while they were writing. Spotted mistakes were gathered into groups and a new text with similar mistakes was made by the researcher. The participants were asked to spot and correct the mistakes in the text. Then, the mistakes they made and the mistakes they corrected in the new text were compared. It was observed that teacher candidates were able to spot the same mistakes they made when they were made by another participant. In conclusion, it could be said that teacher candidates know about the mistakes that cause incoherence but they still make similar mistakes while constructing a text. The reasons that caused this situation were researched by debating with the teacher candidates.

Keywords: Teaching Turkish, writing education, expressive language disorder.

\footnotetext{
${ }^{*}$ Yrd. Doç. Dr., Bülent Ecevit Üniversitesi Üniversitesi, Eğitim Fakültesi, Türkçe Eğitimi Bölümü. e-posta: flzmt27@gmail.com
} 


\section{Giriş}

Hızla küreselleşen günümüz dünyasında yazılı ve sözlü iletişim daha da önem kazanmıştır. İnsanın tüm hayatı boyunca içinde bulunduğu iletişim biçimleri ve dil etkinliklerinin iki temel amacı vardır. Bunlardan birisi okunan, dinlenen, izlenen herhangi bir mesajı anlamak; diğeri de görüleni, duyulanı, tasarlananları en açık ve anlaşılabilir şekilde karşı tarafta bulunanlara anlatmaktır (Göçer, 2014:517).

Türkçe öğretiminde temel hedef öğrencinin dil becerilerini geliştirebilmektir. Dil becerileri, anlama ve anlatma temeline dayanmaktadır. Anlama dört dil becerisinden olan okuma ve dinleme becerilerini, anlatma ise konuşma ve yazma becerilerini kapsamaktadır.

Duygu, düşünce ve hayallerin, istek ve arzuların, bilinen ve görülenlerin, okunan veya duyulanların dil aracılı̆ı̀la kâğıt üzerine güzel ve etkili bir şekilde aktarılmasına yazma; topluluk halinde yaşayan insanların duygu, düşünce ve tasarılarının, dil kurallarına göre, doğru ve etkileyici bir biçimde plan çerçevesinde yazıyla anlatılmasına yazılı anlatım denir (Calp, 2005:195). Yazma, beyinde yapılandırılmış bilgilerin yazıya dökülmesidir (Güneş, 2007:159). Yazılı anlatım, düşünceyi sistematize etmeyi, yazıyı planlamayı, dil bilgisi kurallarına uymayı, sentez yapmayı vb. gerektirir (Sever 2000:20). Buradan yola çıkarak yazma becerisinin geliştirilmesinde öğrencinin öncelikle dil bilgisi kurallarını öğrenmesi ve sahip olduğu bilgiyi yazarken uygulaması gerektiği söylenebilir. Bireyler, günlük hayatta birbirleriyle olan iletişimlerinde ihtiyaçları, duygu, yaşantı, düşünce, hayal ve isteklerini konuşarak veya yazarak dile getirirler. Yazma becerisi öğrencilerin genellikle en zorlandıkları dil becerisidir.

Türkçe öğretmenlerinin, öğrencilere yazma becerisinin geliştirilmesi konusunda rehberlik edebilmesi öncelikle kendilerinin yazma becerisi ile ilgili bilgiye ve beceriye sahip olmasına bağlıdır. Bu maksatla Türkçe öğretmeni yetiştiren Türkçe Eğitimi Bölümlerinin lisans programında lisans eğitiminin 6. döneminde yer alan ve 2 saati teorik 2 saati uygulama olan Yazma Eğitimi derslerine yer verilmiştir. Yazma Eğitimi dersi ile ulaşılmak istenilen hedef şöyle tanımlanmaktadır: "Yazılı metin türleri konusunda öğrencileri bilinçlendirme ve uygulama çalışmalarıyla öğretmen adaylarının hem öğrenen hem de öğretici kişi olacakları bilinciyle hareket etmeleri için yazma çalışmalarının yapılması." (Lisans Programı, 2011-2012:71).

Bu bağlamda öğretmen adayından beklenti, anlatım bozukluklarından arınmış ve etkili yazılı anlatım metinleri oluşturabilmeleri yönündedir. Lisans programındaki "hem öğrenen hem de öğretici kişi olacakları bilinciyle hareket etmeleri“ ifadesine dayanarak öğretmen adayının öğrenmesi ve öğrendiklerini uygulamasının yanı sıra bir öğretici bilinciyle, mevcut anlatım bozukluklarını tespit edip düzeltebilmesi de beklenmektedir 
Türkçe Öğretmenliği Bölümünde Yazma Eğitimi Dersi: Bilme ve Uygulama Karşılaştırması

Bu çalışmada, öncelikle öğretmen adaylarının kendi oluşturdukları metinler incelenmiş, daha sonra araştırmacı tarafından incelenen metinlerde belirlenen anlatım bozukluklarının eşdeğer örneklerinin bulunduğu metinler oluşturulmuştur. İkinci aşama olarak öğretmen adaylarından oluşturulan metinlerdeki anlatım bozukluklarını tespit ederek düzeltmeler yapmaları istenmiş ve yapılan düzeltmeler incelemeye alınmıştır. Adayların düzeltme yaptıkları yanlışlar ve kendi yaptıkları yanlışlar tek tek karşılaştırılmış ve belirlenen sonuçlarla ilgili öğretmen adaylarıyla görüşülerek ortaya çıkan farkın nedenleri veya nasıl açıklanabileceği açık uçlu bir soru olarak sorulmuştur.

Bu çalışma ile öğretmen adaylarıyla ilgili aşağıdaki sorulara cevap aranmıştır:

- Öğretmen adaylarının yazılı ifadelerde yaptıkları anlatım bozuklukları hangi başlıklar altında yoğunlaşmaktadır?

- Öğretmen adaylarının başkalarının yaptığı anlatım bozukluklarını tespit edip düzeltebilme oranı nedir?

- Öğretmen adaylarının oluşturduğu metinlerdeki anlatım bozukluğu oranı ile var olan anlatım bozukluğunu tespit edip düzeltebilme oranı arasında farklılık var mıdır?

- Öğretmen adayları hangi nedenlerle kendi yazılı ifadelerinde anlatım bozuklukları yapmaktadır?

\section{Yöntem}

Bu bölümde araştırmanın modeli, araştırma için belirlenen çalışma grubu, araştırmada kullanılan veri toplama araçları ve verilerin analizlerinde kullanılan istatistik teknikleri ile ilgili açıklamalar yer almaktadır.

\section{Araştırmanın modeli}

Türkçe öğretmen adaylarının başkaları tarafından yapılan anlatım bozukluklarını tespit edip düzeltmekte başarılı olurken neden kendi oluşturdukları metinde aynı türden yanlışlar yaptıklarının araştırılması amacı ile yapılan bu çalışmada nicel ve nitel veriler sunması bakımından karma araştırma özelliği taşıyan tarama modeli kullanılmıştır.

Nitel araştırma yöntemi kapsamındaki verilerin analizinde başka bir ifade ile Türkçe öğretmen adaylarının başkaları tarafından yapılan anlatım bozukluklarını tespit edip düzeltmekte başarılı olurken kendi oluşturdukları metinde aynı türden yanlışlar yapmalarının nedenlerini belirleyebilmek için "temelde yapılan işlem, birbirine benzeyen verileri belirli kavramlar ve temalar çerçevesinde bir araya getirmek ve bunları okuyucunun anlayabileceği bir biçimde düzenleyerek yorumlamak" (Yıldırım ve Şimşek, 2008: 227) olan içerik analizi ve betimsel analiz tekniği kullanılmıştır.

“içerik analizi kapsamında toplanan verileri açıklayabilecek kavramlara ve ilişkilere ulaşmak amacı ile araştırmada elde edilen verilerden çıkarılan kavramlara göre ortak yönleri olan kodlar bulunmuş ve temalar oluşturulmuştur” (Yıldırım ve Şimşek; 2006: 40). "Güvenirliği arttırmak, yanlılı̆ı 
azaltmak ve kategoriler arasında karşılaştırmalar yapabilmek amacıyla" (Yıldırım ve Şimşek, 2006: 40) nitel veriler genel bir çerçeve içinde kodlama yapılarak sayısallaştırılmış ve sözcüklerin sıklık hesapları yapılmıştır. Daha sonra, birbiriyle ilişkili ve anlamlı bir bütün oluşturan kodlar, temalar altında birleştirilmiştir.

Içcerik analizinden elde edilen sonuçları desteklemek amacıyla da betimsel analiz tekniği uygulanmıştır. Betimsel analiz çerçevesinde katılımcıların ilgili konuya yönelik görüşleri değiştirilmeden aktarılmıştır.

\section{Araştırmanın Evren ve Örneklemi}

Çalışmanın kapsamı, katılımcıların oluşturduğu metinler ile araştırmacı tarafından geliştirilen bir metin ile sınırlandırımıştır. Araştırmanın evrenini Türkçe Eğitimi Bölümünde okumakta olan 3. ve 4. sınıf öğrencileri, örneklemini ise araştırmacı tarafından evrenin ulaşılabilen kısmı olan 109 öğrenci oluşturmaktadır. Örneklem olarak kabul edilen, 2013-2014 eğitim öğretim döneminde öğrenim gören 19-24 yaşları aralığındaki 66 kız 43 erkek öğrencidir.

\section{Verilerin Toplanması}

Araştırma sürecinde veri toplama aşamaları aşağıda verilmiştir.

\section{Belge taraması}

Anlatım bozukluklarının hangi temalar altında gruplandırılabileceği ile ilgili geçerli bilgilere ulaşabilmek için belge taraması gerçekleştirilmiş ve anlatım bozuklukları konusu ile ilgili veri toplanmıştır.

\section{Yazma etkinliği}

Katılımcılarla, 30 dakikalık sürede en az 450 kelimelik kompozisyon yazmaları gereken bir yazma etkinliği gerçekleştirilmiştir. Etkinliğin ölçme değerlendirme boyutunda kullanılmayacağı belirtilmiş ve konu seçimi serbest bırakıımıştır. 30 dakikanın sonunda kâğıtlar toplanarak kodlanmıştır. Kodlanan toplam 109 katıımcının kâğıdı incelemeye alınarak anlatım bozuklukları belirlenmiş, daha önce yapılan belge taramasıyla oluşturulmuş başlıklara göre gruplandırıımıştır.

\section{Anlatım bozukluğu tespiti etkinliği}

Çalışmanın bu aşamasında, incelenen kâğıtlarda belirlenmiş anlatım bozukluklarıyla aynı türde yanlışların bulunduğu bir metin oluşturulmuştur. 2 dil uzmanından katılımcıların metinlerinde bulunan ve daha sonra hazırlanan metinde özellikle oluşturulan yanlışların eşdeğer olduğuna ilişkin onay alınmıştır.

Anlatım bozuklukları ile oluşturulmuş hazır metinler aynı katılımcılara dağıtılmıştır. 30 dakika süre verilerek bu kez katılımcılardan metinde anlatım bozukluğu varsa tespit etmeleri ve düzeltmeleri istenmiştir. Katılımcıların yaptığı düzeltmelerin kâğıtları ile bir önceki yazma etkinliğindeki kâğıtları eşleştirilerek aynı kodlar verilmiştir. Bu durumda, iki adet K1 kodlu kâğıt bulunmaktadır. Kâğıtların bir 
Türkçe Öğretmenliği Bölümünde Yazma Eğitimi Dersi: Bilme ve Uygulama Karşılaştırması

tanesinde katılımcının kendi oluşturduğu metin diğerinde ise tespit edip düzelttiği anlatım bozukluklarının olduğu hazır metin bulunmaktadır.

Karşılaştırma

Bu aşamada kodları eşleştirilmiş iki kâğıt bir arada ele alınmıştır. Birinci kâğıtta katılımcıların yazdıkları metinler ikinci kâğıtta ise tespit edip düzelttikleri yanlışların bulunduğu hazır verilen metin bulunmaktadır. Bu kez iki kâğıt bir arada incelemeye alınmış ve tespit edilip düzeltilen yanlışların kendi oluşturdukları metinlerde olup olmadığı belirlenmiştir.

Inceleme sonucunda katılımcıların kendi yaptıkları yanlışlar ile tespit edip düzelttiği yanlışlar sayılarla ifade edilerek karşılaştırımıştır.

Neden araştırması

Bir önceki aşamada yapılan karşılaştırma doğrultusunda anlatım bozukluklarını tespit edip düzeltebilen ancak kendisi metin oluştururken aynı yanlışları yapan katılımcılara bir adet açık uçlu sorudan oluşan anket uygulanmıştır. Ankette anlatım bozukluklarını tespit edip düzeltebilen ancak kendi kâğıtlarında anlatım bozukluğu olan katılımcılara bunun nedenleri sorularak açıklama istenmiş, görüş toplanmıştır.

\section{Geçerlik ve Güvenirlik}

Yapılan araştırmada kullanılmak için hazırlanan metin, katılımcıların yaptıkları anlatım bozukluklarının eşdeğerleri ile oluşturulup oluşturulmadığına ilişkin uygulama öncesinde iki konu uzmanının görüşüne sunulmuş ve onay alınmıştır.

\section{Verilerin Analizi}

Veri analiz sürecinde ilk aşama olarak belge taraması yapılmış, anlatım bozukluklarının hangi başlıklar altında ele alınacağı belirlenerek gruplandırımıştır. Daha sonra, katılımcılardan bir metin oluşturmaları istenmiş ve kâğıtlar toplanarak kodlanmıştır. Kodlanan kâğıtlardaki metinler incelemeye alınmış, anlatım bozuklukları belirlenerek frekans ve yüzdelikler hâlinde tabloda gösterilmiştir. Metinlerin incelenmesi sürecinde her grup için belirlenen ilk yanlış gözden kaçma olarak kabul edilip değerlendirmeye alınmamış, aynı gruptan en az iki yanlış olması durumunda değerlendirmeye dâhil edilmiştir.

Metinlerin incelenmesi ve yanlışların belirlenmesi sonrasında, katılımcıların yaptıkları yanlışlarla eşdeğer olabilecek her gruptan en az iki yanlışın bulunduğu bir metin oluşturulmuştur. Nitel araştırmalarda, araştırılan olgu veya olay hakkında bütüncül bir resim oluşturabilmesi için araştırmacının elde ettiği verileri ve ulaştığı sonuçları teyit ettirmesine yardımcı olacak bazı ek yöntemler (çeşitleme, katılımcı teyidi, meslektaş teyidi, vb.) kullanması gerekir (Yıldırım, Şimşek 1999: 255). Bu aşamada, anlatım bozukluğu bulunan metni oluşturduktan sonra iki dil uzmanından oluşturulan yanlışların katılımcıların yaptıkları yanlışlara eşdeğer sayılıp sayılamayacağı konusunda görüş alınmıştır. 
Bir süre sonra, yaptıkları yanlışların benzerleri ile oluşturulan metin aynı katılımcılara verilerek incelemeleri ve varsa anlatım bozukluklarını tespit ederek düzeltmeleri istenmiştir. Çalışmanın bu aşamasında, katılımcıların düzeltme yaptıkları kâğıtlar toplanmış, kendi yazdıkları metinlerin bulunduğu kâğıtlardaki kodlarla eş olarak kodlanmıştır.

Daha sonra, her katılımcıya ait iki kâğıt bir arada incelemeye alınmıştır. Katılımcıların oluşturdukları metinlerde yaptıkları anlatım bozuklukları ile hazır verilen metindeki aynı türden anlatım bozukluklarını tespit edilebilme durumları karşılaştırılmıştır. Söz konusu karşılaştırma tek tek, bireysel olarak hangi grupta yanlış yapıldıysa aynı gruptaki yanlışı tespit edip düzeltme oranları belirlenerek frekans ve yüzdeye dönüştürülmüştür. Katılımcılara, konuyla ilgili dönüt verilip oluşturdukları metinlerde anlatım bozuklukları bulunduğu ancak aynı tür yanlışların başkaları tarafından yapııdığında tespit edilerek düzeltilebildiği açıklanmış ve bunun nedenleri sorulmuştur. Açık uçlu bir soru biçiminde yapılan anketin cevapları betimsel yöntemle incelenerek görüşler temalar altında toplanmış, frekans ve yüzdelik hesapları belirlenmiştir.

\section{Bulgular ve Yorum}

Bu bölümde araştırmada cevap aranan sorulara ilişkin toplanan verilerin analiz sonuçlarından elde edilen bulgulara ve yorumlara yer verilmiştir.

\section{Katılımcıların yazılı ifadelerde yaptıkları anlatım bozuklukları hangi başlıklar altında yoğunlaşmaktadır?}

Tablo 1. Yazma etkinliğinde yapılan anlatım bozuklukları

\begin{tabular}{|c|c|c|c|}
\hline \multirow{7}{*}{ 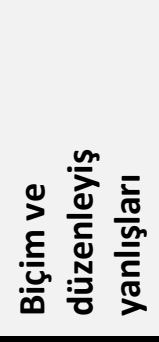 } & & frekans & yüzde \% \\
\hline & Biçimsel yanlışlar & 48 & 44.03 \\
\hline & Anlatım yanlışları & 76 & 69.72 \\
\hline & Düzenleyiş yanlışları & 21 & 19.26 \\
\hline & Noktalama yanlışları & 72 & 66.05 \\
\hline & Mantıksal yanlışlar & 19 & 17.43 \\
\hline & Yazma yanlışları & 17 & 15.59 \\
\hline \multirow{2}{*}{ 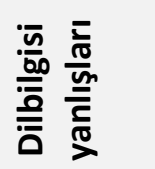 } & Sözcük ve eklerin kullanım yanlışları & 17 & 15.59 \\
\hline & Söz dizimi yanlışları & 13 & 11.92 \\
\hline
\end{tabular}

Tablo3.1. incelendiğinde biçim ve düzenleyiş yanlışları grubunda toplam 109 katılımcıdan 48 kişinin (\%44.03) biçimsel yanlışlar, 76 kişinin (\%69.72) anlatım yanlışları, 21 kişinin (\%19.26) düzenleyiş yanlışları, 72 kişinin (\%66.05) noktalama yanlışları, 19 kişinin (\%17.43) mantıksal yanlışlar, 17 kişinin (\%15.59) yazma yanlışları bulunduğu tespit edilmiştir. İkinci grup olan dilbilgisi yanlışlarında ise toplam 109 katılımcıdan 17 kişinin (\%15.59) sözcük ve eklerin kullanımında yanlışlar, 13 kişinin (\%11.92) ise söz dizimi yanlışları bulunduğu tespit edilmiştir. 
Öğretmen adaylarının başkalarının yaptığı anlatım bozukluklarını tespit edip düzeltebilme oranı nedir?

Tablo 2. Anlatım bozukluğu tespiti etkinliğinde düzeltilen anlatım bozuklukları

\begin{tabular}{|c|c|c|c|}
\hline \multirow{7}{*}{ 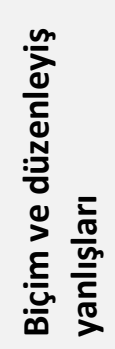 } & \multicolumn{2}{|r|}{ frekans } & yüzde \% \\
\hline & Biçimsel yanlışlar & 96 & 88.07 \\
\hline & Anlatım yanlışları & 67 & 61.46 \\
\hline & Düzenleyiş yanlışları & 44 & 40.36 \\
\hline & Noktalama yanlışları & 89 & 81.65 \\
\hline & Mantıksal yanlışlar & 50 & 45.87 \\
\hline & Yazma yanlışları & 98 & 89.90 \\
\hline \multirow{2}{*}{ 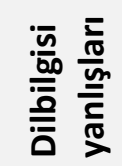 } & Sözcük ve eklerin kullanım yanlışları & 93 & 85.32 \\
\hline & Söz dizimi yanlışları & 102 & 93.57 \\
\hline
\end{tabular}

Tablo3.2. incelendiğinde yanlışların tespiti etkinliğinde biçim ve düzenleyiş grubundaki biçimsel yanlışları toplam 109 katılımcıdan 96 kişinin (\%88.07), anlatım yanlışlarını 67 kişinin (\%61.46), düzenleyiş yanlışlarını 44 kişinin (\%40.36), noktalama yanlışlarını 89 kişinin (\%81.65), mantıksal yanlışları 50 kişinin (\%45.87), yazma yanlışlarını 98 kişinin (\%89.90) tespit ettiği belirlenmiştir. Dil bilgisi grubundaki sözcük ve eklerin kullanım yanlışlarını ise toplam 109 katılımcıdan 93 kişinin (\%85.32), söz dizimi yanlışlarını 102 kişinin (\%93.57) tespit ettiği belirlenmiştir.

Öğretmen adaylarının oluşturduğu metinlerdeki anlatım bozukluğu oranı ile var olan anlatım bozukluğunu tespit edip düzeltebilme oranı arasında farklılık var mıdır?
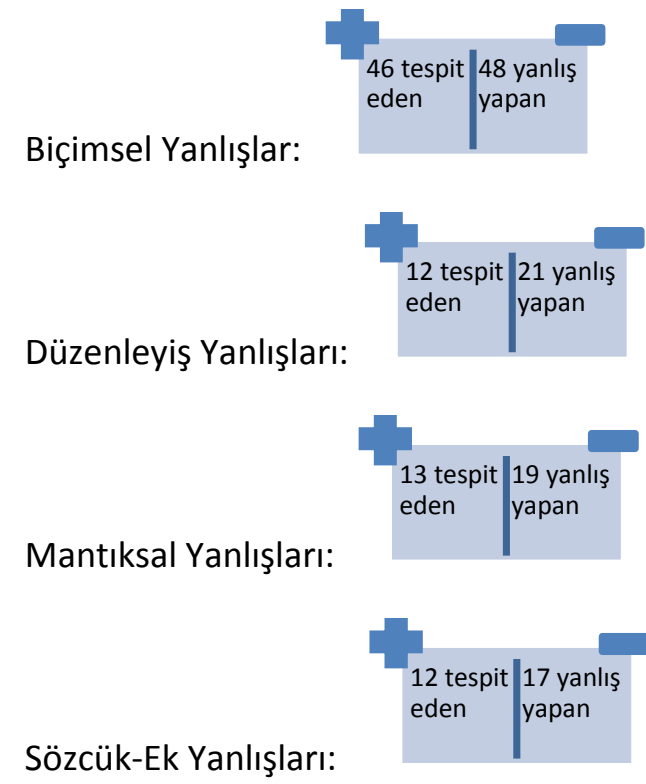

Anlatım Yanlışları:
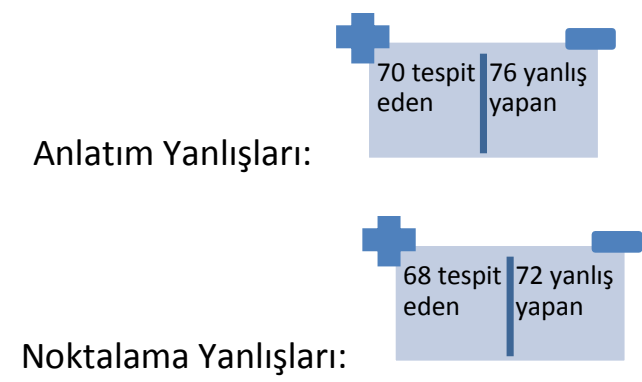

Yazma Yanlışları:

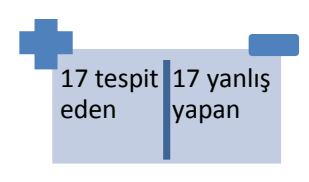

Söz dizimi Yanlışları:

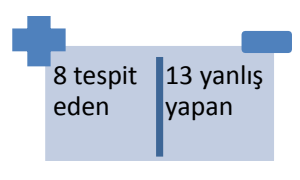


Anlatım bozukluğu yapan katılımcıların kendi yazdıkları metinlerin bulunduğu kâğıtlar ile hazır verilen metnin anlatım bozukluğunu tespit ettikleri kâğıtlar birebir karşılaştıııldığında ortaya çıkan sonuca göre; toplam 109 katılımcıdan biçimsel yanlışlar yapan 48 kişinin 46'sının (\%95.83), anlatım yanlışları yapan 76 kişinin 70'inin (\%92.10), düzenleyiş yanlışları yapan 21 kişinin 12'sinin (\%57.14), noktalama yanlışları yapan 72 kişinin 68'inin (\%94.44), mantıksal yanlışlar yapan 19 kişinin 13'ünün (\%68.42), yazma yanlışları yapan 17 kişinin 17 'sinin (\%100.00), sözcük ve eklerin kullanımında yanlış yapan 17 kişinin 12'sinin (\%70.58), söz dizimi yanlışları yapan 13 kişinin ise 8'inin (\%61.53) yanlışları tespit edip düzelttiği belirlenmiştir.

Inceleme sonucuna göre; öğretmen adaylarının anlatım bozukluklarını tespit edip düzeltme oranı, kendileri yazarken yaptıkları anlatım bozuklukları oranından çok daha yüksektir. Bu bağlamda katılımcıların anlatım bozukluğu yaptığı ancak var olan anlatım bozukluklarını çok büyük oranda tespit edebildiği ve düzeltebildiği anlaşılmaktadır. Bu durum, yeterli teorik bilgiye sahip olduğu hâlde öğretmen adaylarının uygulama sürecinde sorunlar yaşadığı şeklinde yorumlanabilir.

Ancak, teoride bilinenin neden uygulama sürecinde kullanılmadığı açıklanamamaktadır. Bu bağlamda katılımcıların konu ile ilgili açıklamalarına ihtiyaç duyulmuş ve yazarken anlatım bozuklukları yapma nedenleri sorulmuştur.

\section{Katılımcılar hangi nedenlerle anlatım bozuklukları yapmaktadır?}

Katılımcılara kendi yaptıkları anlatım bozuklukları hakkında dönüt verilmiştir. Bunun ardından sadece kendi yaptıkları yanlışları başkaları yaptığında tespit edip düzeltebilen katılımcılara neden bu yanlışları yaptıkları açık uçlu bir soru olarak sorulmuştur. Katılımcıların açıklamalarına ilişkin verilen cevaplar gruplandırılarak temalar hâlinde aşağıdaki tabloda yer almaktadır.

Çalışmanın bu aşamasına yazma etkinliği sırasında anlatım bozukluğu yapmayan katılımcılar dâhil edilmemiştir. Bu nedenle toplamda 109 olan katılımcı sayısı 97'ye düşmüştür.

Tablo 4. Nedenlerle ilgili görüşler

\begin{tabular}{lcc}
\hline & frekans & yüzde \% \\
Sürenin sınırlı olması & 27 & 27.83 \\
İçerikteki bilgiye daha fazla önem verme & 13 & 13.40 \\
Bilgileri yeteri kadar aktaramama endişesi & 6 & 6.18 \\
Dikkatsizlik & 26 & 26.80 \\
Değerlendirilme kaygısı, heyecan, & 16 & 16.49 \\
Yazma eyleminden hoşnutsuzluk & 7 & 7.21 \\
Önemsememe & 2 & 2.06 \\
Toplam & $\mathbf{9 7}$ & $\mathbf{1 0 0}$ \\
\hline
\end{tabular}


Türkçe Öğretmenliği Bölümünde Yazma Eğitimi Dersi: Bilme ve Uygulama Karşılaştırması

Katılımcılara serbest yazma etkinliğinde yaptıkları anlatım bozukluklarının nedenleri sorulduğunda, belirli bir süre verilmesinin tedirginlik yaratarak yanlışlara neden olduğu görüşü en yüksek oranda bildirilen madde olarak tespit edilmiştir. Bu tedirginliğin ise yetersiz süre verilmesinden değil, süre ne olursa olsun yetiştirememe kaygısından kaynaklandığı belirtilmektedir. Yıllarca süren öğrencilik döneminde, öğretmen adaylarının girdiği sınavların, bilgi sınavı olmaktan çıkıp bir hız ve psikolojik dayanıklılık sınavına dönüşmesinin bu tür kaygılara neden olduğu söylenebilir.

Bunun durumun sonucu olarak sınırlı süre verildiğinde yaşanan zamana karşı yarışma alışkanlığı, yazma etkinliğinde dikkat eksikliği yaratmakta ve anlatım bozukluklarına yol açabilmektedir. A11 kodlu katılımcı yaptığı anlatım bozukluklarını "Süre bitmeden yazayım, yetişeyim derken heyecandan noktalama işaretleri kullanmak aklıma gelmiyor." şeklinde belirtmiştir.

Yazma etkinliğinde süre kısıtlamasının yanlışlara yol açtığını dile getiren A37 kodlu katılımcı ise “ Eğer süre kısaysa acele yazmaya çalıştığımdan yazdığımı okumaya fırsat kalmıyor. Ama yazdıklarımı okumaya zamanım olursa çoğunu düzeltiyorum." diyerek yazma ve okuma ilişkisi kurmaktadır. Benzer şekilde A63 kodlu katılımcı da "Ben yazarken yanlış olduğunu düşünmüyorum ama okurken gözüme çarpıyor." diye açıklamaktadır. Bu bağlamda yapılan anlatım bozukluklarını yüksek oranda dikkatsizlik diye açıklayan katılımcıların süre kısıtlaması olmasa büyük oranda yaptıkları yanlışları tespit edip düzeltebilecekleri söylenebilir. Ayrıca A3 kodlu katııımcının “Öncelik içeriği oluşturmada. İ̧̧erik daha önemli geldiğinden detaylar dikkatimden kaçıyor." açıklaması sınırlı sürede bilgi aktarma kaygısından dolayı öğretmen adaylarının yazııı anlatımda yazııı anlatım kurallarını ikinci öncelik sıralamasına atma eğiliminde olduklarının göstergesi sayılabilir.

Dikkat çeken bir diğer nokta öğretmen adaylarına yaptıkları anlatım bozukluklarının nedeni sorulduğunda, yazmayı önemsemedikleri ve yazmaktan hoşlanmadıkları yönünde yapılan açıklamalar olmuştur. Yazmaktan hoşlanmadığını belirten katılımcıların tamamına yakınının erkek olması düşündürücü bir sonuçtur. Bununla birlikte Ceran'ın yaptığı araştırmada ortaya çıkan, “Kız öğretmen adaylarının yazma eğitimi dersine yönelik tutumları, erkek öğretmen adaylarının tutumuna göre daha olumludur." sonucuyla örtüşmektedir.

A23 kodlu katılımcının neden anlatım bozukluğu yaptığıyla ilgili açıklaması ise noktalama işaretleri ve imla kurallarıyla ilgili değişikliklere sitem olarak "Kurallar bu kadar sık değiştirilirse nasıl öğrenebiliriz ki...Her an elimde yeni imla kılavuzuyla gezemem." şeklinde olmuştur.

Verilerin birleştirilmesi ve katılımcılardan elde edilen görüşlerin incelenmesinin ardından öğretmen adaylarının anlatım bozukluklarıyla ilgili yeterli düzeyde bilgi sahibi oldukları ancak söz konusu etkenlerden dolayı uygulamada sorunlar yaşadıkları söylenebilir. 


\section{Tartışma ve Sonuç}

Öğrenciye yazma becerisi kazandıracak kişi öğretmendir. Bu beklentiden hareketle öğretmen adayının yazma eğitimiyle ilgili teorik bilgi düzeyinin yeterli olması gerekmektedir. Ancak teorik bilginin uygulamaya dönüşmesi öğretmen adayları için bir gerekliliktir. Eyüp (2012), özetleme stratejilerini kullanma konusunda yaptığı bir çalışmada Türkçe öğretmeni adaylarının uygulama sürecinde yetersiz kaldıkları sonucuna ulaşmıştır. Bu durum, teorik olarak bilmenin uygulamadaki yetersizlikleri engelleyemeyeceği şeklinde açıklanmaktadır.

Bu çalışmada ise öğretmen adaylarının yazılı ifadelerinde anlatım bozukluğu bulunma oranı yüksek olsa da var olan anlatım bozukluklarını tespit edebilme oranının çok daha üst düzeyde olduğu belirlenmiştir. Bu durumda bilişsel eksiklikten bahsetmek geçerli olmayacaktır. Bu bağlamda öğretmen adaylarının anlatım bozukluğunu yüksek oranda tespit edebildiği için konu hakkında bilgi sahibi olduğu kabul edilebilir. Çalışmada ortaya çıkan sonuca göre; öğretmen adaylarının anlatım bozukluğunu tespit edip düzeltebildiğine bağlı olarak bilişsel düzeylerinin yeterli ancak bilgiyi kendisinin uygulamasında yetersiz olduğu söylenebilir.

Çalışmada elde edilen sonucu destekler nitelikte Çamurcu (2011) da yaptığı Yüksek Öğrenime Yeni Başlayan Türkçe Eğitimi Bölümü Öğrencilerinin Yazma Becerilerinin İncelenmesi adlı araştırmasında Türkçe öğretmeni adaylarının yazma becerilerini incelemiş ve duygu ve düşüncelerini yazılı olarak ifade edebilme düzeylerinin düşük olduğunu tespit etmiştir.

Benzer şekilde Ayyıldız ve Bozkurt'un (2006) yaptığı Edebiyat ve Kompozisyon Eğitiminde Karşılaşılan Sorunlar başlıklı araştırmanın sorunların tespitindeki sonuçlar da yazma eğitimiyle ilgili yazım yanlışlarının bulunduğu, çok sayıda noktalama yanlışı görüldüğü, özne yüklem uyuşmazlıklarının, kip uyuşmazlıklarının, sözcüğün yanlış ya da gereksiz kullanımına dayanan yanlışların yaygın olduğu yönündedir.

Ceran (2013) Türkçe öğretmeni adaylarının yazma eğitimi dersine karşı tutumlarını belirlemek amacıyla yaptığı araştırma sonucunda dersin gerekliliğine, faydasına ve önemine inanan öğrencilerin yazı yazmaktan uzak durduklarını belirlemiştir. Elde ettiği sonucu yazma kaygısıyla açıklamıştır.

Başarıı bir yazılı anlatımın gerçekleşebilmesi sağlam ve zengin bir kelime hazinesine sahip olmaya, bol ve dikkatli okumaya, iyi bir gözlemci olmaya, dilin özelliklerini ve inceliklerini bilmeye, geniş düşünmeye, duygu ve düşünceleri mantıklı ve ahenkli bir düzen içinde sunabilmeye, özgün olmaya ve yazma işini zevkle yapabilmeye bağlıdır (Deniz, 2003:242).

Öğretmen adayları, karşılaştıkları dil bilgisi yanlışlarını belirleme ve düzeltmede başarılı olduğunda konuyla ilgili yeterli bilgi düzeyine sahip oldukları söylenebilmektedir. Ancak, bilgilerini ikinci plana öteledikleri ve yazarken neden aynı tür yanlışları kendilerinin yaptıklarını izah etmek zordur. Yanlışların nedenini açıklayan öğretmen adaylarına göre doğru yazmak için gereken süre ve ortamın 
yaratılması, ayrıca sınav kaygısından arındırılmış bir süreç oluşturulması bu yanlışları büyük oranda engelleyecektir.

\section{Kaynakça}

Aksan, D. (1990). Her Yönüyle Dil, Türk Dil Kurumu Yayınları: 439, Ankara.

Aksoy, Ö. A. (1991). Dil Yanlışları, Adam Yayınları, İstanbul.

Ayyıldız, M. ve Bozkurt, Ü. (2006). Edebiyat ve Kompozisyon Eğitiminde Karşılaşılan Sorunlar, Türk Eğitim Bilimleri Dergisi, S. 4 (1), s. 45-52.

Calp, M. (2005). Özel Öğretim Alanı Olarak Türkçe Öğretimi. Konya: Eğitim Kitabevi.

Ceran, D. (2013). Türkçe Öğretmeni Adaylarının Yazma Eğitimi Dersine Yönelik Tutumlarının Değerlendirilmesi, Turkish Studies - International Periodical For The Languages, Literature and History of Turkish or Turkic, Volume 8/1, p. 1151-1169.

Çamurcu, D. (2011). Yüksek Öğrenime Yeni Başlayan Türkçe Eğitimi Bölümü Öğrencilerinin Yazma Becerilerinin İncelenmesi, Türkiyat Araştırmaları Dergisi, 7/29, s. 503-518.

Deniz, K.. (2003). Yazılı Anlatım Becerileri Bakımından Köy ve Kent Beşinci Sınıf Öğrencilerinin Durumu, Türklük Bilimi Araştırmaları (Türkçenin Öğretimi Özel Sayısı, S. 13, s. 233-255.

Eyüp, B., Stebler, Z. ve Yurt, U. S. (2012). Türkçe Öğretmeni Adaylarının Özetleme Stratejilerini Kullanmadaki Eğilimleri, Dil ve Edebiyat Eğitimi Dergisi, 1/1, s. 22-30.

Göçer, A. (2014). Yazma Tutum Ölçeği'nin (YTÖ) Türkçeye Uyarlanması: Geçerlik ve Güvenirlik Çalışması, Kastamonu Eğitim Dergisi, Cilt:22, No:2 s. 515-524.

Güneş, F. (2007). Türkçe Öğretimi ve Zihinsel Yapılandırma, Nobel Yayıncılık, Ankara.

Hatiboğlu, N. (1998). Üniversitede Türk Dili Dersleri, Yazılı ve Sözlü Anlatım, Birlik Ofset, Eskişehir.

Necmettin Erbakan Üniversitesi Ahmet Keleşoğlu Eğitim Fakültesi, Lisans ve Tezsiz Yüksek Lisans Programı. 2011- 2012 Eğitim Öğretim Yılı.

Tiryaki, E. N. (2012). Üniversite Öğrencilerinin Yazma Kaygısının Çeşitli Değişkenler Açısından Belirlenmesi, Dil ve Edebiyat Eğitimi Dergisi, 1/1, s. 14-21.

Yıldırım, A. ve Şimşek, H. (2006). Sosyal Bilimlerde Nitel Araştırma Yöntemleri. Ankara: Seçkin Yayınları. 